\title{
Investigating Immunological Parameters and Quantification of Rhoptry Pseudokinases Gene Expression in Toxoplasmosis
}

NIYAN INAAM MUHAMMED YOUSIF*AND HADI MAHDI AHMAD ALSAKEE

Microbiology Unit, Basic Science Department, College of Medicine, Hawler Medical University, Erbil, Kurdistan Region, Iraq

Yousif et al.: Immunological Parameters and Rhoptry Pseudokinases Gene Expression in Toxoplasmosis

Toxoplasma affects about one-third of the world's population and is a common disease between humans and animals. The most common cause of toxoplasmosis is infection with Toxoplasma gondii. The main virulence factors of Toxoplasma gondii in toxoplasmosis are rhoptry pseudokinases. The aim of this study was to evaluate the seroprevalence and immunological parameters of toxoplasmosis and investigate the expression of rhoptry protein 5, rhoptry protein 16 and rhoptry protein 18 genes in women in Erbil. Also, evaluation of the serum levels of interleukin-12 and interleukin-6 in women with recurrent miscarriage were performed. In this study, 300 women at their reproductive age who referred to Maternity Teaching Hospital of Erbil were registered. Enzyme linked immunosorbent assay technique has been applied to detect anti toxoplasma immunoglobulin $G$ and immunoglobulin M. Statistical analysis was done via statistical package for the social sciences version 21.0 and the $p$ value of $\leq \mathbf{0 . 0 5}$ was considered as statistically significant. A total of 50 seropositive samples with and without history of miscarriage were tested by polymerase chain reaction for detection of rhoptry protein 5 , rhoptry protein 16 and rhoptry protein 18 genes using home designed primers. A significant association was found between toxoplasmosis and history of abortion, but no association was found between toxoplasmosis and education level, socioeconomic status, age and residence. According to the results, the interleukin-6 level was non-significantly ( $p>0.05)$ changed in infected women. Nevertheless, serum interleukin-12 level was remarkably $(p<0.05)$ elevated in infected women compared to control group. Polymerase chain reaction targeting both toxoplasma genes detected more abortive cases than non-abortive one among anti-toxoplasma seropositive women. The results of quantification and detection of rhoptry protein 5 , rhoptry protein 16 and rhoptry protein 18 genes of Toxoplasma gondii among 50 samples by polymerase chain reaction, confirmed the expression of these genes in toxoplasmosis condition. Finally, it was concluded that the prevalence of toxoplasmosis has increased in Erbil women and the level of interleukin-12 in the serum of women infected with Toxoplasma gondii has increased significantly. Also, rhoptry protein 5, rhoptry protein 16 and rhoptry protein 18 genes can be used as markers in the first level of toxoplasmosis. Therefore, quantification of these genes can help in determining Toxoplasma gondii strain virulence.

Key words: Toxoplasma gondii, cytokines, interleukin-12, interleukin-6, rhoptry protein 5

Toxoplasma gondii (T. gondii) (a member of the phylum Apicomplexa) is a ubiquitous apicomplexan parasites of human and others warm blooded animals which have been measured as the cause of most prevalent parasitic zoonosis ${ }^{[1,2]}$ and is the causative representative of significant morbidity and mortality among human worldwide ${ }^{[3]}$.

Nearly one third of the world's population is infected by this obligate intracellular protozoan parasite ${ }^{[4]}$. Infections with $T$. gondii typically occur by ingestion of water or food contaminated by oocysts shed by $T$. gondii infected cats or by assimilation of tissue cysts in meat from $T$. gondii infected animals ${ }^{[5]}$. While the congenital transmission is also expansively reported and represents a public health problem ${ }^{[6]}$. Congenital infection arises only when a woman becomes infected during pregnancy ${ }^{[7]}$. About one third of all the women who gain infection with $T$. gondii during pregnancy spread the parasite to the fetus ${ }^{[8]}$. After primary maternal infection by $T$. gondii during gestation, the parasite may arrive the fetal circulation by infection of the placenta.

*Address for correspondence

E-mail: Niyan.innam@gmail.com 
The risk and severity of infection in the child rely on the time of gestation in which the mother acquires the infection $^{[9]}$.

Fetal toxoplasmosis, predominantly in early pregnancy can cause miscarriage, stillbirth and birth defects ${ }^{[10]}$. Early first trimester maternal infection is less prospective to result in congenital infection, but the squeal is more severe ${ }^{[3]}$. The recognition of recently acquired infection in pregnant women is, therefore, dangerous for clinical management of the mother and her fetus ${ }^{[11]}$. The clinical spectrum of $T$. gondii infections differs from asymptomatic to life threatening disease $\mathrm{e}^{[5]}$. Since the infection is associated with no signs or non-specific symptoms in the great majority of individuals, mainly those with efficient immune systems and pregnant women, the diagnosis of toxoplasmosis primarily relies on serological tests. The detection and quantification of T. gondii antibodies in serum is used to found whether the infection acquired recently or in the distant past ${ }^{[12]}$. Enzyme linked immunosorbent assay (ELISA) is the most common test accessible as commercial kits and automated platform. It is a biochemical technique used to distinguish the presence of antibody or antigen in a sample. The discovery of specific immunoglobulin $\mathrm{M}$ ( $\operatorname{IgM}$ ) and immunoglobulin $\mathrm{G}$ (IgG) antibodies has been used as serological marker for diagnosing current toxoplasmosis ${ }^{[13]}$. As an obligate intracellular parasite, T. gondii must attack host cells to survive and develop the infection.

During cell invasion, two subcellular organelles, micronemes and rhoptries, sequentially discharge their contents at the apical end of the parasite to mediate entry. As the parasite invades the host cell, a parasitophorous vacuole (PV) membrane is formed and surrounds the parasite. After the parasite finishes entry, other organelles, termed as dense granules (DG), secrete proteins into the PV. Dense granule proteins are supposed to function in modification of the PV for nutrient acquisition ${ }^{[14]}$. The $T$. gondii infection results in a strong and persistent $\mathrm{T}$ helper 1 (Th1) response considered by creation of proinflammatory cytokines including interleukin-12 (IL-12). It is known that IL-12 is produced by human dendritic cells, neutrophils and monocytes in response to $T$. gondii. Resistance to the intracellular protozoan parasite $T$. gondii is originated by the induction of IL-12, which stimulates interferon gamma (IFN- $\gamma$ ) synthesis by natural killer (NK) cells and $\mathrm{T}$ lymphocytes ${ }^{[15]}$.

The crucial virulence factors of $T$. gondii are rhoptry pseudokinases (ROPs). A family of rhoptry pseudokinases (rhoptry protein 5 (ROP5)) is expressed by the protozoan parasite, $T$. gondii ${ }^{[16]}$. The main acute virulence determinant is the pseudokinase ROP5 which is expressed by $T$. gondii ${ }^{[17]}$. The active rhoptry kinase rhoptry protein 18 (ROP18) is the main determinant of the difference between highly virulent and avirulent parasites. It has various targets in the host cell ${ }^{[18]}$. The ROP5 and ROP18 gene alleles are highly predictive of virulence in $T$. gondii. rhoptry protein 16 (ROP16) is considered as a virulence factor that plays a major role during the primary infection in humans ${ }^{[19]}$.

Therefore, the diagnosis of toxoplasmosis is mostly based on serological tests. Detection and measurement of $T$. gondii antibodies in serum is used to detect the stage of infection. On the other hand, investigating the expression of rhoptry pseudokinases is important in toxoplasmosis. Therefore the aim of this study was evaluating the seroprevalence and immunological parameters of toxoplasmosis, detecting the antitoxoplasma $\operatorname{IgG}$ and $\operatorname{IgM}$ and investigating the expression of ROP5, ROP16 and ROP18 genes in women in Erbil.

\section{MATERIALS AND METHODS}

\section{Seroprevalence and immunological parameters:}

A cross sectional study was carried out in Erbil city in which 300 women in their reproductive age who attended Maternity Teaching Hospital from October 2018 to March 2019 were enrolled. An informative close end questionnaire including age, residency, socioeconomic level, history and number of abortions, history and number of abnormal parities, gestational age, was obtained through direct interview. The participants were apparently healthy and women with autoimmune diseases such as rheumatoid arthritis, systemic lupus erythematosus (SLE) and those with urinary tract infection (UTI) (vaginal discharge, burning during urination, dysuria), were excluded from the study.

\section{Ethical considerations:}

The study was approved by the research ethical committee of the College of Medicine, Hawler Medical University, Erbil. A verbal consent was obtained from each participant before collection of blood samples.

\section{Sample collection:}

$5 \mathrm{ml}$ of blood was withdrawn using a sterile syringe and transferred to a clean fully labeled tube, then centrifuged at $3000 \mathrm{rpm}$ for $10 \mathrm{~min}$ to separate the serum. The 
separated serum was dispensed into two Eppendorf tubes fully labeled with the required information according to the questionnaire sheet designed for the study and stored at $-20^{\circ}$ until used. The seroprevalence of toxoplasma antibodies was determined using ELISA technique. The ELISA kits were supplied by Bioactive Company (Germany). The procedure was done according to the manufacturer's instructions supplied with the kit.

\section{C-reactive protein (CRP):}

One hundred sera samples were examined by C-reactive protein (CRP) for control group: the samples which showed serological tests negative to anti T.gondii IgG/IgM antibody were enrolled in the control group. CRP was estimated by latex fixation method via a kit (Spinreact SA, Spain) following the manufacturer's instructions.

\section{Quantitative estimation of human interleukin-12 (IL-12) and interleukin-6 (IL-6) by ELISA:}

The Human IL-12 and IL-6 ELISA Kits (Komabiotech, Korea) were used for quantitative estimation of IL-12 and IL-6 in the sera samples of the case group which showed serological tests positive to anti $T$. gondii $\mathrm{IgG} / \mathrm{IgM}$ antibody and control group which showed serological tests negative to anti $T$. gondii $\operatorname{IgG} / \operatorname{IgM}$ antibody by CRP in accordance with the leaflet provided by the manufacturer.

\section{Statistical analysis:}

The Statistical Package for Social Science (SPSS version 21.0) was used for data entry and analysis. The student t-test and Chi square were used to compare the data, $p$ value of $\leq 0.05$ was considered as statistically significant.

\section{Detection and quantification of gene expression:}

A total of 50 seropositive samples with and without history of miscarriage were tested by polymerase chain reaction (PCR) for detection of ROP5, ROP16 and ROP18 genes using home designed primers.

\section{RESULTS AND DISCUSSION}

A total of 300 women agreed to be involved in the study. The age of the participants ranged between 18 to $48 \mathrm{y}$ with a mean age of $27.36 \pm 6.28 \mathrm{y}$. Half of the participants $152(50 \%)$ had antibodies for T. gondii. Anti-Toxoplasma IgG and IgM were seropositive in $129(43 \%)$ and $14(4.7 \%)$ women, respectively. Only $9(3 \%)$ of women who were seropositive for toxoplasmosis carrying both anti toxoplasma $\operatorname{IgG}$ and IgM as exnressed in fig. 1.

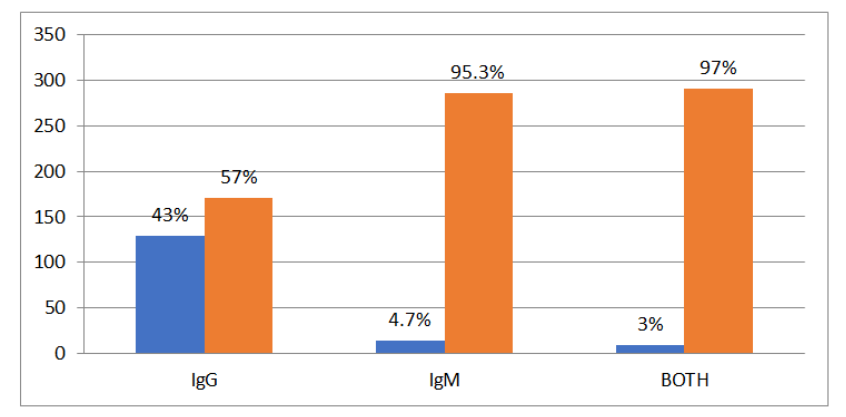

Fig. 1: Prevalence of anti-toxoplasma IgM and IgG antibodies among 300 women of Erbil city, ( $\square$ ) Positive, ( $\square$ ) Negative

As it can be seen in Table 1, significant association of toxoplasmosis and history of miscarriage was observed on screening for both anti-Toxoplasma IgG and IgM antibodies (5.9 \% vs. $1.1 \%$ ) by ELISA in women with and without history of miscarriage, respectively.

In respect to the socioeconomic level of the participants, the results revealed highest rate of anti-T. gondii IgG $(27.7 \%), \operatorname{IgM}(2.7 \%)$, both $\operatorname{IgG}$ and $\operatorname{IgM}(2.3 \%)$ among women with low socioeconomic level, however, statistically no significant association was observed between toxoplasmosis and socioeconomic level as revealed in Table 2.

According to educational level of the participants, no significant $(\mathrm{p}>0.05)$ association of toxoplasmosis and educational level was observed Table 3.

In the current study, the age of the participants ranged between 18 to $48 \mathrm{y}$ with a mean age of $27.36 \pm 6.28 \mathrm{y}$. Comparably, the results revealed that, highest rate of anti-toxoplasma (IgG 22.7 \%; IgM $3.1 \%$; IgG and IgM, $2 \%$ ) antibodies were among women with ages ranged between 21-30 y old. However, statistical analysis revealed no significant differences in the levels of $\mathrm{IgG}$ $(p=0.355), \operatorname{IgM}(p=0.575)$, both $\operatorname{IgG}$ and $\operatorname{IgM}(p=0.571)$ antibodies among the studied age groups (Table 4).

As it can be seen in Table 5, the seroprevalence of toxoplasmosis among studied women in relation to their residency, the highest rates, 65 (21.7\%), 9 (3\%), $5(1.7 \%)$ were observed among women who were rural inhabitants by IgG, IgM, both IgG and IgM respectively. However, statistical analysis revealed no significant differences among urban and rural inhabitants for antitoxoplasma $\operatorname{IgG}$, IgM, both $\operatorname{IgG}$ and $\operatorname{IgM}(\mathrm{p}=0.604$, $\mathrm{p}=0.231, \mathrm{p}=0.467$ ) antibodies (Table 5). 
TABLE 1: SEROPREVALENCE OF TOXOPLASMOSIS AMONG WOMEN ACCORDING TO HISTORY OF MISCARRIAGE

\begin{tabular}{|c|c|c|c|c|}
\hline \multirow[b]{2}{*}{ History of miscarriage } & \multirow[b]{2}{*}{$\begin{array}{l}\text { No. of examined } \\
\text { samples }\end{array}$} & $\lg G$ & $\lg M$ & IgG and IgM \\
\hline & & $\begin{array}{c}\text { Seropositive samples } \\
\text { (\%) }\end{array}$ & $\begin{array}{c}\text { Seropositive samples } \\
\text { (\%) }\end{array}$ & $\begin{array}{c}\text { Seropositive samples } \\
\text { (\%) }\end{array}$ \\
\hline Yes & 118 & $48(16.0)$ & $10(3.3)$ & $7(2.3)$ \\
\hline No & 182 & $81(27.0)$ & $4(1.3)$ & $2(0.7)$ \\
\hline Total & 300 & $129(43)$ & $14(4.7)$ & $9(3.0)$ \\
\hline$p$ value & $\mathrm{p}=0.513$ & $p=0.012$ & $\mathrm{p}=0.017$ & $42.37 \pm 14.16^{*} \#$ \\
\hline
\end{tabular}

TABLE 2: SEROPREVALENCE OF TOXOPLASMOSIS AMONG WOMEN ACCORDING TO SOCIOECONOMIC LEVEL

\begin{tabular}{|c|c|c|c|c|}
\hline \multirow[b]{2}{*}{ Socioeconomic level } & \multirow{2}{*}{$\begin{array}{l}\text { No. of examined } \\
\text { samples }\end{array}$} & $\lg G$ & $\lg M$ & $\lg M$ and $\lg G$ \\
\hline & & $\begin{array}{l}\text { Seropositive samples } \\
\text { (\%) }\end{array}$ & $\begin{array}{l}\text { Seropositive samples } \\
\text { (\%) }\end{array}$ & $\begin{array}{c}\text { Seropositive samples } \\
\text { (\%) }\end{array}$ \\
\hline Low & 183 & $83(27.7)$ & $8(2.7)$ & $7(2.3)$ \\
\hline Medium & 105 & $42(14)$ & $4(1.3)$ & $1(0.3)$ \\
\hline High & 12 & $4(1.3)$ & $2(0.7)$ & $1(0.3)$ \\
\hline Total & 300 & $129(43)$ & $14(4.7)$ & $9(3)$ \\
\hline$p$ value & $\mathrm{p}=0.533$ & $\mathrm{p}=0.152$ & $\mathrm{p}=0.136$ & $p$ value \\
\hline
\end{tabular}

TABLE 3: SEROPREVALENCE OF TOXOPLASMOSIS AMONG WOMEN ACCORDING TO EDUCATIIONAL LEVEL

\begin{tabular}{lccccc}
\hline \multirow{2}{*}{ Education } & No. of examined & IgG & IgM & IgG and IgM & Total \\
\cline { 3 - 5 } & samples & $\begin{array}{c}\text { Seropositive } \\
\text { samples (\%) }\end{array}$ & $\begin{array}{c}\text { Seropositive } \\
\text { samples (\%) }\end{array}$ & $\begin{array}{c}\text { Seropositive } \\
\text { samples (\%) }\end{array}$ & Seropositive (\%) \\
\hline Primary & 64 & $25(8.3)$ & $1(0.3)$ & $1(0.3)$ & $27(17.7)$ \\
Secondary & 75 & $28(9.3)$ & $2(0.7)$ & $0(0.0)$ & $30(19.7)$ \\
University & 52 & $53(17.7)$ & $8(2.7)$ & $6(2.0)$ & $67(44)$ \\
Illiterate & 109 & $53(17.7)$ & $8(2.7)$ & $6(2.0)$ & $67(44)$ \\
Total & 300 & $129(43)$ & $14(4.7)$ & $9(3.0)$ & $152(50.6)$ \\
p value & & $\mathrm{p}=0.419$ & $\mathrm{p}=0302$ & $\mathrm{p}=0.123$ & $\mathrm{p}=0.113$ \\
\hline
\end{tabular}

TABLE 4: AGE DISTRIBUTION OF ANTI-TOXOPLASMA ANTIBODIES AMONG WOMEN WITH TOXOPLASMOSIS

\begin{tabular}{lcccc}
\hline \multirow{2}{*}{ Age } & $\begin{array}{c}\text { No. of examined } \\
\text { samples }\end{array}$ & IgG & IgM & IgG and IgM \\
\cline { 3 - 5 } & 52 & Seropositive sample (\%) & Seropositive samples (\%) & Seropositive samples (\%) \\
\hline$\leq 20$ & 156 & $68(22.7)$ & $1(0.3)$ & $0(0.0)$ \\
$21-30$ & 87 & $41(13.7)$ & $9(3)$ & $6(2)$ \\
$31-40$ & 5 & $2(0.7)$ & $4(1.3)$ & $3(1)$ \\
$\geq 41$ & 230 & $129(43)$ & $0(0)$ & $0(0)$ \\
Total & $\mathrm{p}=0.355$ & $\mathrm{p}=0.575$ & $14(4.7)$ & $9(3.0)$ \\
$\mathrm{p}$ value & & $\mathrm{p}=0.571$ & $\mathrm{p}$ value \\
\hline
\end{tabular}


TABLE 5: SEROPREVALENCE OF TOXOPLASMOSIS AMONG WOMEN ACCORDING TO HISTORY OF RESIDENCY

\begin{tabular}{|c|c|c|c|c|}
\hline \multirow{2}{*}{ Residency } & \multirow{2}{*}{$\begin{array}{l}\text { No. of examined } \\
\text { samples }\end{array}$} & $\lg G$ & $\lg M$ & IgG and IgM \\
\hline & & Seropositive samples (\%) & Seropositive samples (\%) & Seropositive \\
\hline Urban & 155 & $64(21.3)$ & $5(1.7 \%)$ & $4(1.3 \%)$ \\
\hline \multirow[t]{2}{*}{ Rural } & 145 & $65(21.7)$ & $9(3.0 \%)$ & $5(1.7 \%)$ \\
\hline & 300 & $129(43)$ & $14(4.7 \%)$ & $9(3.0 \%)$ \\
\hline$p=0.575$ & $p=0.575$ & $p=0.575$ & $p=0.575$ & $p=0.575$ \\
\hline
\end{tabular}

A total of 50 samples tested by PCR for detection of ROP5, ROP16 and ROP18 genes by home designed primers, $11(22 \%)$ and $22(44 \%)$ of them showed positive results for ROP5 and ROP16 respectively. 7 (14\%) of them showed positive results for ROP18. PCR targeting T. gondii ROP16 gene was more efficient (Table 6, fig. 2).

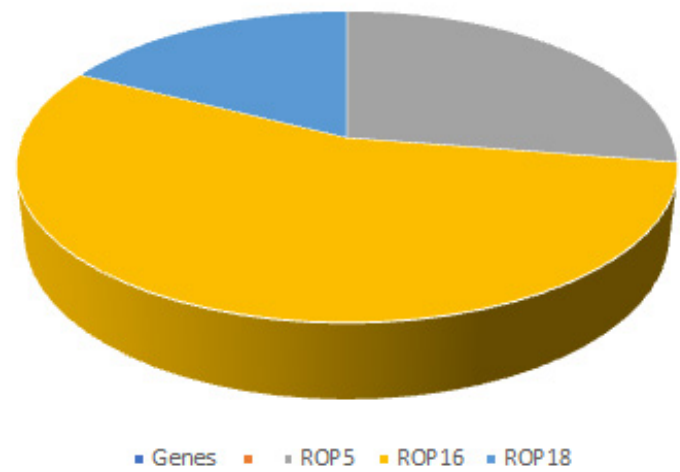

Fig. 2: The frequency of ROP5, ROP16 and ROP18 genes in 50 seropositive samples by PCR

Table 7 shows the results of molecular detection of toxoplasmosis in blood of women with and without history of miscarriage that showed seropositive results for anti-Toxoplasma IgM and IgG by ELISA. ROP5, ROP16 and ROP18 genes were positive in $8(16 \%), 18$
$(36 \%)$ and $6(12 \%)$ of abortive women, respectively versus $3(6 \%) 4$ (8\%) and 1 (2\%) for ROP5, ROP16 and ROP18, respectively in non-abortive women. Comparably but not significantly, for ROP5 $(\mathrm{p}=0.498)$ and ROP18 ( $\mathrm{p}=0.229)$, there were no differences between women with miscarriage and those without miscarriage, in regard of ROP5 and ROP18, while there was a significant association of ROP16 $(\mathrm{p}=0.010)$ and history of miscarriage. PCR targeting both toxoplasma genes detected more abortive cases than non-abortive one among anti-Toxoplasma seropositive women (fig. 3).

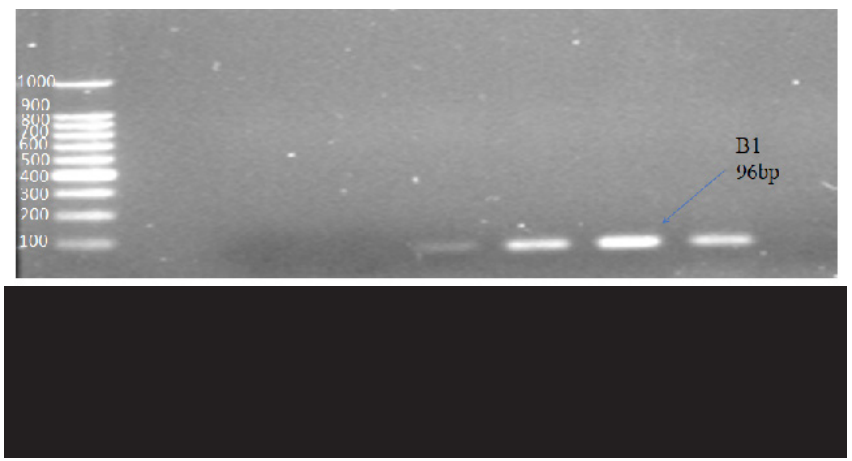

Fig. 3: PCR amplification of B1 gene of T. gondii genome on $2 \%$ agarose gel using primers specific for $T$. gondii, positive samples revealed 96 bp bands for $B 1$ gene

Lane 1: DNA ladder. Lane 2, 3, 4 and 9: negative samples for $B 1$.

Lane: 5, 6, 7, 8 are positive samples for $B 1$ gene

TABLE 6: THE FREQUENCIES OF ROP5, ROP16 AND ROP18 GENES AMONG 50 SEROPOSITIVE SAMPLES WITH AND WITHOUT HISTORY OF MISCARRIAGE BY PCR

\begin{tabular}{lcccc}
\hline \multirow{2}{*}{ Genes } & \multicolumn{2}{c}{ Positive samples } & \multicolumn{2}{c}{ Negative samples } \\
\cline { 2 - 5 } & Number & Percentage (\%) & Number & Percentage (\%) \\
\hline ROP5 & 11 & 22 & 39 & 78 \\
ROP16 & 22 & 44 & 28 & 56 \\
ROP18 & 7 & 14 & 43 & 86 \\
\hline
\end{tabular}


TABLE 7: MOLECULAR DETECTIN OF ROP5, ROP16 AND ROP18 GENES OF T. GONDII AMONG 50 SAMPLES BY PCR IN TERMS OF HISTORY OF MISCARRIAGE

\begin{tabular}{lcccc}
\hline History of miscarriage & $\begin{array}{c}\text { No. of examined } \\
\text { samples }\end{array}$ & $\begin{array}{c}\text { Positive samples } \\
\text { number and } \\
\text { percentage }\end{array}$ & $\begin{array}{c}\text { Positive samples } \\
\text { number and } \\
\text { percentage }\end{array}$ & $\begin{array}{c}\text { Positive samples } \\
\text { number and } \\
\text { percentage }\end{array}$ \\
\hline Yes & 31 & $8(25.8 \%)$ & $18(58.1 \%)$ & $6(19.4 \%)$ \\
No & 19 & $3(15.8 \%)$ & $4(21.1 \%)$ & $1(5.3 \%)$ \\
Total & 50 & $11(22 \%)$ & $22(44 \%)$ & $7(14 \%)$ \\
p value & & $\mathrm{p}=0.498$ & $\mathrm{p}=0.010$ & $\mathrm{p}=0.229$ \\
\hline
\end{tabular}

Out of 50 blood samples that were collected from pregnant women, conventional PCR analysis for $T$. gondii ROP5, ROP16 and ROP18 genes revealed that $11(22 \%)$ and $22(44 \%)$ of the total samples, demonstrated the $144 \mathrm{bp}$ band of $T$. gondii ROP5 and $260 \mathrm{bp}$ band of $T$. gondii ROP16 respectively. Only 7 (14\%) demonstrated 74 bp band for ROP18 (fig. 4-7).

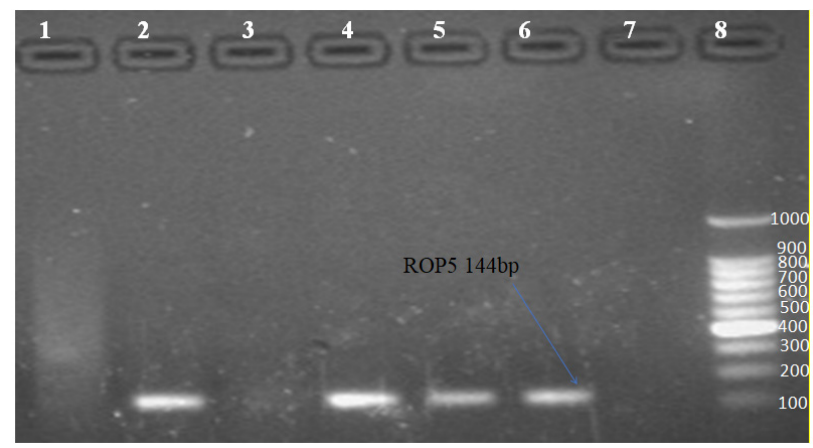

Fig. 4: PCR amplification of ROP5 gene of T. gondii genome on $2 \%$ agarose gel using primers specific for $T$. gondii, positive samples revealed 144 bp bands for ROP5

Lane 1, 3, 4, 5: positive samples for ROP5. Lane 7: DNA Ladder and Lane 2 and 6 are negative samples for ROP5 gene

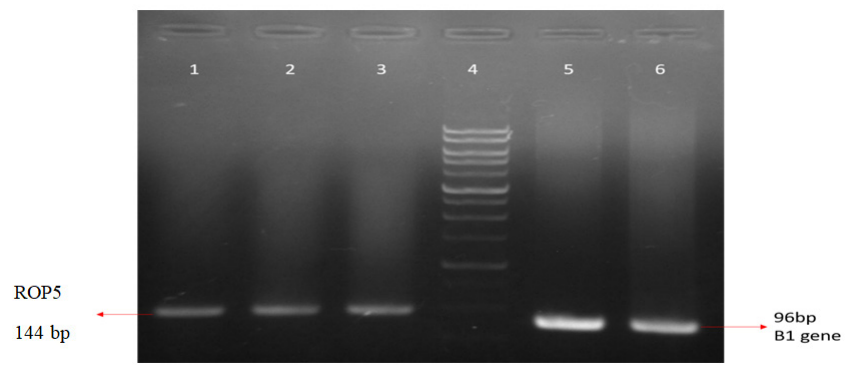

Fig. 5: PCR amplification of B1 and ROP5 genes of $T$. gondii genome on $2 \%$ agarose gel using primers specific for $T$. gondii, positive samples reveal 96 bp bands for B1 gene and 144 bp bands for ROP5

Lane 1, 2 \& 3: positive samples for ROP5. Lane 4: DNA Ladder and Lane 5 and 6: $\mathrm{B} 1$ gene positive

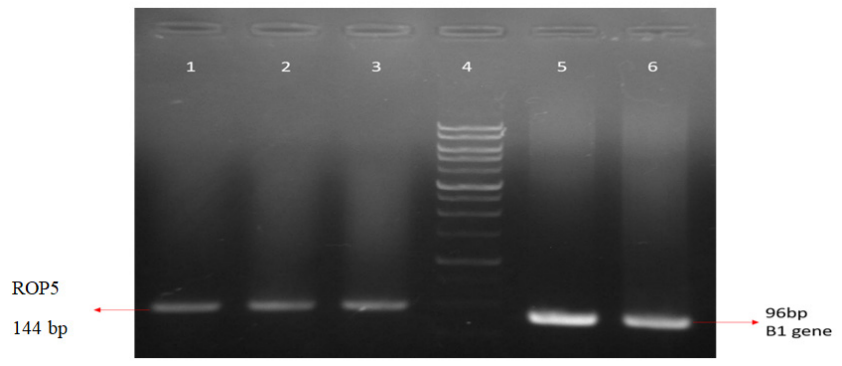

Fig. 6: PCR amplification of ROP16 gene of $T$. gondii genome on $2 \%$ agarose gel, using primers specific for $T$. gondii, positive samples reveal 260 bp bands for ROP16 gene

Lane 1 DNA marker (100 bp ladder), Lane 2, 3, 4, 5, 8, 9 and 11 are positive samples, Lane 6,7 and 10 are negative samples

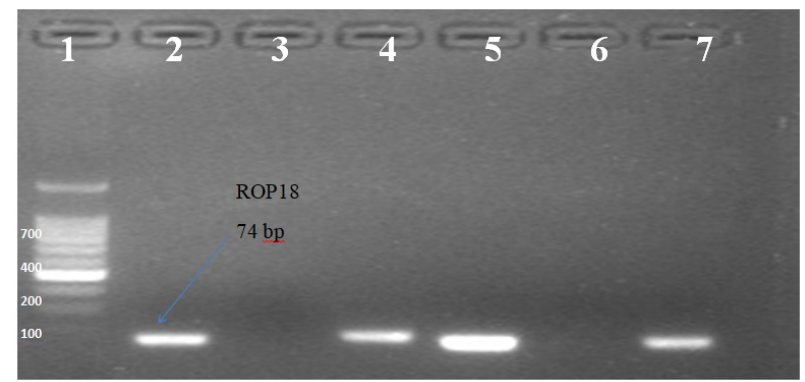

Fig. 7: PCR amplification of ROP18 gene of T. gondii genome on $2 \%$ agarose gel. Positive samples reveal 74 bp bands for ROP18 gene

Lane 1: DNA marker (100 bp ladder), Lane $2,4,5,7$ are positive samples, Lane 3 and 6 are negative samples

Patients in this study did not differ on any of the demographic variables examined. Regarding the age of the participants, the highest levels of anti-toxoplasma (IgG $22.7 \%$; IgM $3 \%$; IgG and IgM $2 \%$ ) antibodies has observed among ages between 21-30 y old although, no significant association was revealed by statistical analysis. In Sudan, the estimated seroprevalence of toxoplasmosis increased between the ages of 21 and 
30. Because this is the most fertile childbearing age for women, they are at high risk ${ }^{[20]}$. Another study carried out in Saudi Arabia concluded that the highest level of toxoplasmosis was observed in women as they get older (63\%); this is due to the increased risk of exposure to the $T$. gondii parasite ${ }^{[21]}$.

However, in the present study, no significant association of anti-toxoplasma antibodies and the socioeconomic level was observed. Women with low socioeconomic status may be at risk of recurrent infections as a result of the unhygienic environment in which they live ${ }^{[22]}$. In addition, the current study found no statistically significant differences in toxoplasmosis among pregnant women and educational levels, suggesting that educational levels have no impact on infection. This finding is consistent with the result as obtained by Kamal et al. 2015 in Egypt ${ }^{[23]}$. On the other hand, a study done by Malarvizhi et al. (2012) in India demonstrated that the infection was more prevalent among illiterate women ${ }^{[24]}$. This controversy may be referred into the date of investigations and information growth in the world of media and social networks.

Another interesting finding was that significant correlation between toxoplasmosis and history of abortion in screening for both anti-Toxoplasma IgG and $\operatorname{IgM}$ antibodies in women with and without a history of abortion observed. Serological screening of the toxoplasmosis among 300 pregnant and non-pregnant women with and without a history of abortion revealed that $129(43 \%)$ of the samples had a positive IgG, 14 (4.7\%) IgM and 9 of the cases (3\%) had a positive both IgG and IgM. Comparably, these results are consistent with previous studies that carried out in Erbil. Abdulla et al. $(2017)^{[25]}$ reported that the seroprevalence levels of toxoplasmosis were 92 (34.98\%) and 34 (12.93\%) for $\mathrm{IgG}$ and $\mathrm{IgM}$, respectively, among women who referred to Teaching Maternity Hospital in Erbil from December 2015 to April 2016. Also, Bakre et al. (2016) ${ }^{[3]}$ observed $15.3 \%$ and $5.3 \%$ positive cases for IgG and IgM, respectively. In Duhok province, Iraq, the seroprevalence levels relation to some demographic factors were found to be $282(35.61 \%)$ for $\mathrm{IgG}$ and $6(0.76 \%)$ for IgM among females ${ }^{[26]}$. In Basra, a study involving pregnant women found $\operatorname{IgG}$ and $\operatorname{IgM}$ seroprevalence levels of $11.3 \%$ and $1.13 \%$ respectively, among female university students of childbearing age $^{[27]}$. Another research conducted in Baghdad, Iraq on 120 women who had spontaneous abortions found that $43.33 \%$ were positive for anti-toxoplasma antibodies, with $4.16 \%$ having IgM, $25.83 \%$ having IgG and
$13.33 \%$ having both $\operatorname{IgM}$ and $\operatorname{IgG}$ positive reactions. Subsequently, the authors have clarified the possible association between toxoplasmosis and the occurrence of abortion ${ }^{[28]}$. Furthermore, the infection rate was also recorded in some neighboring countries, such as Iran, where Sharifi et al. found that (23.2\%) and (7.2\%) of women had chronic and acute infections, respectively ${ }^{[29]}$. Anti T. gondii $\operatorname{IgG}$ and $\operatorname{IgM}$ antibodies were found to be $20 \%$ and $6.2 \%$, respectively, in another study conducted by Aqeely et al. (2014) in Saudi Arabia ${ }^{[30]}$. One of the most common causes of abortion in pregnant women is toxoplasmosis. The majority of miscarriages occur during the acute phase of infection and in the first trimester of pregnancy ${ }^{[31]}$. A study from Southwest of Iran showed different results to this study; after testing the sera of 130 abortive and 130 non-abortive women by ELISA, no statistical difference ( $>0.05 \%$ ) was detected between toxoplasma infection and abortion ${ }^{[32]}$.

The highest rates of toxoplasmosis, 65 (21.7\%), 9 (3 $\%)$ and $5(1.7 \%)$, were found in women who were rural residents by $\operatorname{IgG}, \operatorname{IgM}$ and both $\operatorname{IgG}$ and $\operatorname{IgM}$ respectively, in the current report. The prevalence of toxoplasmosis in humans is related to a variety of risk factors ${ }^{[33]}$. Consumption of vegetables treated with polluted water, among other risk factors, may have increased the prevalence of toxoplasmosis in a rural area. Other risk factors for toxoplasmosis include personal hygiene, eating habits and socioeconomic status.

In this research, the mean concentration of IL-12 in the sera of women with toxoplasmosis $(232.81 \pm 51.58)$ was significantly higher than that in the healthy control group (152.96 \pm 37.90$)$. In response to T. gondii infection, however, the amount of IL-6 did change significantly. $T$. gondii, an intracellular protozoan, is the causative agent of toxoplasmosis. It plays a crucial role in abortion and congenital diseases in pregnant women, all of which result in an infant's birth defect. Toxoplasmosis is one of the most common and successful parasitic infectious diseases in the world, mainly due to its rapid spread ${ }^{[26]}$. Toxoplasmosis significantly increases IL-12 and IL-6 levels. Toxoplasmosis exposure, according to some in vitro studies, stimulates IL-12 secretion from human monocytes $^{[34]}$; in turn, IL-12 promotes the production of IFN- $\gamma$, a key mediator of human immunity. The most crucial cytokine produced in response to $T$. gondii infection is IFN- $\gamma^{[35]}$. Furthermore, IFN- $\gamma$ controls the intracellular parasite in a cell autonomous manner; additionally, IFN- $\gamma$ inhibits parasitic replication in the human body by increasing tryptophan degradation in 
human fibroblasts. Otherwise, IL-6 secretion is essential for maintaining a normal pregnancy and reducing the risk of spontaneous abortion ${ }^{[36]}$.

The results of quantification and detection of ROP5, ROP16 and ROP18 genes of $T$. gondii among 50 samples by PCR, confirmed the expression of these genes in toxoplasmosis condition. These findings showed the importance of ROP5, ROP16 and ROP18 in determining $T$. gondii strain virulence. Rego et al. (2017) concluded that in determining T. gondii virulence in mice, the virulence protein ROP18, analyzed alone or in combination with ROP5, was effective ${ }^{[37]}$. The results of the study of Dubey et al. (2014) showed that there is an association between genotypes of ROP5 and ROP18 with mouse virulence of $T$. gondii genotypes ${ }^{[38]}$. As a result, the seroprevalence of toxoplasmosis is relatively high in Erbil and the IL-12 level was significantly elevated in the sera of toxoplasmosis infected women.

In conclusion, according to the findings of this study, toxoplasmosis seroprevalence and immunological parameters are significantly elevated in infected women, particularly serum IL-12 in women with recurrent abortion. However, significant changes in IL-6 levels were observed; additionally, rural inhabitant women have higher seroprevalence. As a result, the study suggests that seroprevalence and immunological parameters have to be screened among pregnant women to assess the severity and presence of infection in pregnant women in order to prevent infection spread. Also, ROP5, ROP16 and ROP18 genes can be used as markers in the first level of toxoplasmosis. Therefore, quantification of these genes can help in determination of $T$. gondii strain virulence.

\section{Conflict of Interests:}

The authors declared no conflict of interest.

\section{REFERENCES}

1. Michel N, Sama LF, Kamgue OG, Tchenkam VP, Wam EC. Seroprevalence of Toxoplasma gondii IgG and IgM antibodies and associated risks factors in tuberculosis patients admitted at the Bamenda regional hospital, NW Cameroon. Arch Clin Microbiol 2020;11(1):104.

2. Sabry MA, Reda WW. Infection by cyst producing Protozoa among human and food producing animals in Egypt. J Biol Sci 2008;8:889-95.

3. Bakre HM. Serological tests and polymerase chain reaction for detection of Toxoplasma gondii infection in women attending for premarital examination. Zanco J Med Sci 2016;20(3):147684.

4. Borkakoty B, Biswas D, Jakharia A, Mahanta J. Seroprevalence of Toxoplasma gondii among pregnant women in Northeast India. J Assoc Physicians India 2016;64(10):24-8.
5. Alvarado-Esquivel C, Pacheco-Vega SJ, Salcedo-Jaquez M, Sanchez-Anguiano LF, Hernandez-Tinoco J, Rabago-Sanchez E, et al. Stillbirth history and Toxoplasma gondii infection in women attending public health centers in a northern Mexican City. Eur J Microbiol Immunol 2015;5(2):164-71.

6. de Melo RP, Wanderley FS, Porto WJ, de Morais Pedrosa $\mathrm{C}$, Hamilton CM, de Oliveira MH, et al. Description of an atypical Toxoplasma gondii isolate from a case of congenital toxoplasmosis in northeastern Brazil. Parasitol Res 2020;119(8):2727-31.

7. Hill D, Dubey JP. Toxoplasma gondii: transmission, diagnosis and prevention. Clin Microbiol Infect 2002;8(10):634-40.

8. Ichhpujani RL, Mittal V. Toxoplasmosis-An update. Trop Parasitol 2011;1:9-14.

9. Elbez-Rubinstein A, Ajzenberg D, Darde ML, Cohen $\mathrm{R}$, Dumetre A, Yera $\mathrm{H}$, et al. Congenital toxoplasmosis and reinfection during pregnancy: case report, strain characterization, experimental model of reinfection and review. J Infect Dis 2009;199(2):280-5.

10. Saadatnia G, Golkar M. A review on human toxoplasmosis. Scand J Infect Dis 2012;44(11):805-14.

11. Laliberte J, Carruthers VB. Host cell manipulation by the human pathogen Toxoplasma gondii. Cell Mol Life Sci 2008;65(12):1900-15.

12. Aldebert D, Durand F, Mercier C, Brenier-Pinchart MP, Cesbron-Delauw MF, Pelloux H. Toxoplasma gondii triggers secretion of interleukin-12 but low level of interleukin-10 from the THP-1 human monocytic cell line. Cytokine 2007;37(3):206-11.

13. Khan IA, Ouellette C, Chen K, Moretto M. Toxoplasma: immunity and pathogenesis. Curr Clin Microbiol Rep 2019;6(1):44-50.

14. Goldstein EJ, Montoya JG, Remington JS. Management of Toxoplasma gondii infection during pregnancy. Clin Infect Dis 2008;47(4):554-66.

15. Singh S. Mother-to-child transmission and diagnosis of Toxoplasma gondii infection during pregnancy. Indian J Med Microbiol 2003;21(2):69-76.

16. Etheridge RD, Alaganan A, Tang K, Lou HJ, Turk BE, Sibley LD. The Toxoplasma pseudokinase ROP5 forms complexes with ROP18 and ROP17 kinases that synergize to control acute virulence in mice. Cell Host Microbe 2014;15(5):537-50.

17. Reese ML, Shah N, Boothroyd JC. The Toxoplasma pseudokinase ROP5 is an allosteric inhibitor of the immunityrelated GTPases. J Biol Chem 2014;289(40):27849-58.

18. Shwab EK, Jiang T, Pena HF, Gennari SM, Dubey JP, Su C. The ROP18 and ROP5 gene allele types are highly predictive of virulence in mice across globally distributed strains of Toxoplasma gondii. Int J Parasitol 2016;46(2):141-6.

19. Hernandez-de-Los-Rios A, Murillo-Leon M, Mantilla-Muriel LE, Arenas AF, Vargas-Montes M, Cardona N, et al. Influence of two major Toxoplasma gondii virulence factors (ROP16 and ROP18) on the immune response of peripheral blood mononuclear cells to human toxoplasmosis infection. Front Cell Infect Microbiol 2019;9:413.

20. Mustafa M, Fathy F, Mirghani A, Mohamed MA, Muneer MS, Ahmed AE, et al. Prevalence and risk factors profile of seropositive Toxoplasma gondii infection among apparently immunocompetent Sudanese women. BMC Res Notes 2019;12(1):1-6.

21. Alzaheb RA, Al-Amer O. The seroprevalence and risk factors of toxoplasmosis among female undergraduate university students in Saudi Arabia. Oman Med J 2017;32(6):486. 
22. Iddawela D, Vithana SM, Ratnayake C. Seroprevalence of toxoplasmosis and risk factors of Toxoplasma gondii infection among pregnant women in Sri Lanka: a cross sectional study. BMC Public Health 2017;17(1):1-6.

23. Kamal AM, Ahmed AK, Abdellatif MZ, Tawfik M, Hassan EE. Seropositivity of toxoplasmosis in pregnant women by ELISA at Minia University Hospital, Egypt. Korean J Parasitol 2015;53(5):605.

24. Malarvizhi A, Viswanathan T, Lavanya V, Moorthy K. Seroprevalence of Toxoplasma gondii in pregnant women. J Public Health Epidemiol 2012;4(6):170-7.

25. Abdullah HM, Mahmood MA. Seroprevalence of Toxoplasma gondii among pregnant women in Erbil City/Kurdistan Region/ Iraq. Polytech J 2017; 7:54-63.

26. Salih JM, Mohammed W, Mero S, Eassa SH, Jm S, Res IJ. Seroprevalence and some demographic factors associated with Toxoplasma gondii infection among female population in Duhok province, Iraq. Int J Res Med Sci 2020;8(3):921-6.

27. AL-Sadoon MA, Nasir MA, Yasir ET, Khalaf AO, Kadim SJ. Toxoplasmosis and risk factors among female students of medical colleges at Basra University, Iraq. Biomed Pharmacol J 2018;11(4):2117-22.

28. Mahmood SH, Hassani HH, Zghair KH. Detection of B1 gene of Toxoplasma gondii in blood of pregnant and abortive women infected with this parasite. Iraqi J Med Sci 2010;8(3):42-8.

29. Sharifi K, Farash BR, Fatemeh TA, Khaledi A, Sharifi K, Shamsian SA. Diagnosis of acute toxoplasmosis by IgG and IgM antibodies and IgG avidity in pregnant women from Mashhad, eastern Iran. Iran J Parasitol 2019;14(4):639.

30. Aqeely H, El-Gayar EK, Perveen Khan D, Najmi A, Alvi A, Bani I, et al. Seroepidemiology of Toxoplasma gondii amongst pregnant women in Jazan Province, Saudi Arabia. J Trop Med $2014 ; 2014$.

31. Kheirandish F, Fallahi S, Mahmoudvand H, Araban A, Anbari K, Rouzbahani AK, et al. A loop-mediated isothermal amplification (LAMP) assay for detection of Toxoplasma gondii infection in women with spontaneous abortion. Arch Microbiol 2021;203(2):763-9.
32. Saki J, Mohammadpour N, Moramezi F, Khademvatan S. Seroprevalence of Toxoplasma gondii in women who have aborted in comparison with the women with normal delivery in Ahvaz, southwest of Iran. Sci World J 2015;2015.

33. Cavalcante GT, Aguiar DM, Chiebao D, Dubey JP, Ruiz VA, Dias RA, et al. Seroprevalence of Toxoplasma gondii antibodies in cats and pigs from rural Western Amazon, Brazil. J Parasitol 2006;92(4):863-4.

34. Tosh KW, Mittereder L, Bonne-Annee S, Hieny S, Nutman TB, Singer SM, et al. The IL-12 response of primary human dendritic cells and monocytes to Toxoplasma gondii is stimulated by phagocytosis of live parasites rather than host cell invasion. J Immunol 2016;196(1):345-56.

35. Dupont CD, Christian DA, Hunter CA. Immune response and immunopathology during toxoplasmosis. Semin Immunopathol 2012 34(6):793-813.

36. Bohiltea CL, Radoi VE. Interleukin-6 and interleukin-10 gene polymorphisms and recurrent pregnancy loss in Romanian population. Iran J Reprod Med 2014;12(9):617.

37. Rego WM, Costa JG, Baraviera RC, Pinto LV, Bessa GL, Lopes $\mathrm{RE}$, et al. Association of ROP18 and ROP5 was efficient as a marker of virulence in atypical isolates of Toxoplasma gondii obtained from pigs and goats in Piauí, Brazil. Vet Parasitol 2017;247:19-25.

38. Dubey JP, Van Why K, Verma SK, Choudhary S, Kwok OC, Khan A, et al. Genotyping Toxoplasma gondii from wildlife in Pennsylvania and identification of natural recombinants virulent to mice. Vet Parasitol 2014;200:74-84.

This is an open access article distributed under the terms of the Creative Commons Attribution-NonCommercial-ShareAlike 3.0 License, which allows others to remix, tweak, and build upon the work non-commercially, as long as the author is credited and the new creations are licensed under the identical terms

This article was originally published in a special issue,
"Trends in Therapeutic Management of Various Clinical
Conditions II" Indian J Pharm Sci 2021:83(2)Spl issue;213-221

